\title{
molecules
}

ISSN 1420-3049

www.mdpi.com/journal/molecules

Article

\section{Anti-inflammatory Lignans from the Fruits of Acanthopanax sessiliflorus}

Dae-Young Lee ${ }^{1}$, Kyeong-Hwa Seo ${ }^{2}$, Rak-Hun Jeong ${ }^{2}$, Sang-Min Lee ${ }^{2}$, Geum-Soog Kim ${ }^{1}$, Hyung-Jun Noh ${ }^{1}$, Seung-Yu Kim ${ }^{1}$, Gye-Won Kim ${ }^{3}$, Ji-Young Kim ${ }^{2}$ and Nam-In Baek ${ }^{2, *}$

1 Herbal Crop Utilization Research Team, National Institute of Horticultural and Herbal Science, RDA, Eumseong 369-873, Korea

2 Graduate School of Biotechnology and Department of Oriental Medicinal Materials \& Processing, Kyung Hee University, Yongin 446-701, Korea

3 Brewing Research Center, Han Kyung National University, Ansung 456-749, Korea

* Author to whom correspondence should be addressed; E-Mail: nibaek@khu.ac.kr;

Tel.: +82-31-201-2661; Fax: +82-31-201-2157.

Received: 24 August 2012; in revised form: 10 December 2012 / Accepted: 14 December 2012 /

Published: 21 December 2012

Abstract: A new lignan, named acanthosessilin A (1), as well as eight known lignan and lignan glycosides 2-9 were isolated from an ethanolic extract of Acanthopanax sessiliflorus fruits. The chemical structures were determined by spectroscopic methods, including HR-EIMS, 1D NMR ( ${ }^{1} \mathrm{H},{ }^{13} \mathrm{C}$, DEPT), 2D NMR (gCOSY, gHSQC, gHMBC, NOESY), and IR spectroscopy. All isolated compounds were tested for the ability to inhibit LPS-induced nitric oxide production in RAW264.7 macrophages.

Keywords: Acanthopanax sessiliflorus; lignan; acanthosessilin A; nitric oxide

\section{Introduction}

Acanthopanax sessiliflorus (Rupr. et Maxim) Seem, belonging to the Araliaceae family, is widely distributed in Korea, China, and Japan. The bark and twigs of Acanthopanax species are traditionally used in Korea as anti-rheumatoid arthritis, anti-inflammatory, and anti-diabetic drugs and are recognized to have ginseng-like activities [1,2]. Previous studies on its phytochemicals resulted in the isolation of lignans from the leaves and roots of Acanthopanax species [3-5], and eleutheroside E has been identified as a major compound in the fruits of Acanthopanax species [6]. Lignans are thought to 
be the major active constituents of these plants and are believed to play essential roles in the treatment of diseases [7,8]. However, most phytochemical and pharmacological studies have mainly focused on the leaves, bark, and roots of Acanthopanax species, and only a few reports have investigated the fruits. Acanthopanax species are native medicinal plants and the fruits of Acanthopanax species have been used as a remedy to "wipe out evil wind" in traditional medicine [9]. To further investigate the bioactive constituents derived in the fruits of these species, the present phytochemical study was initiated.

We report herein on the isolation of a new 3,4-dibenzylfuran lignan (1) from the fruits of A. sessiliflorus, together with eight known compounds 2-9, and the structural determination of these substances using extensive spectroscopic methods. Several previous studies have provided evidence for the anti-inflammatory effects of extracts and components from Acanthopanax species [10-12]. Therefore, isolated compounds 1-9 were evaluated for anti-inflammatory activities through the measurement of nitrite, a soluble oxidation product of nitric oxide (NO), in lipopolysaccharide (LPS)-induced RAW 254.7 macrophage cells.

\section{Results and Discussion}

A $70 \%$ ethanolic extract of dried $A$. sessiliflorus fruits was suspended in $\mathrm{H}_{2} \mathrm{O}$ and extracted with EtOAc. The EtOAc soluble fraction was concentrated under reduced pressure to produce a residue that was subjected to multiple chromatographic steps using Sephadex LH-20, silica gel, and reversed-phase C18, yielding compounds 1-9 (Figure 1).

Figure 1. Chemical structures of isolated compounds 1-9.

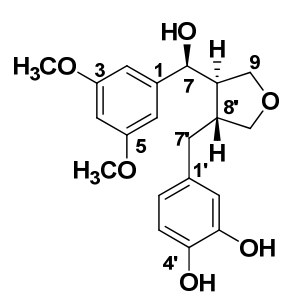

1

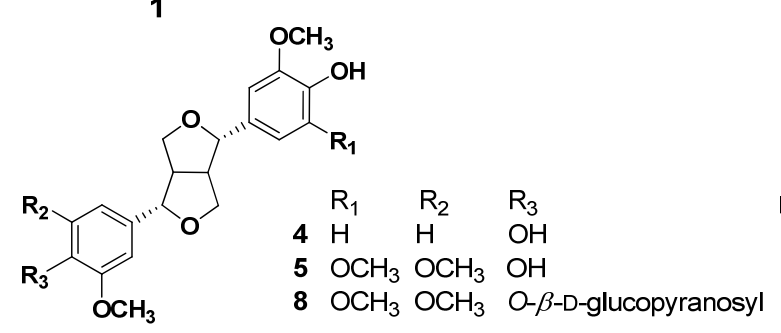

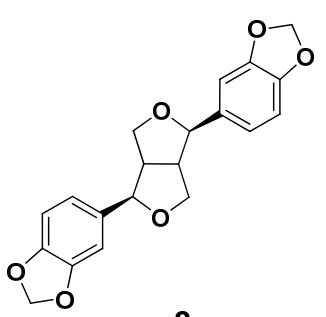

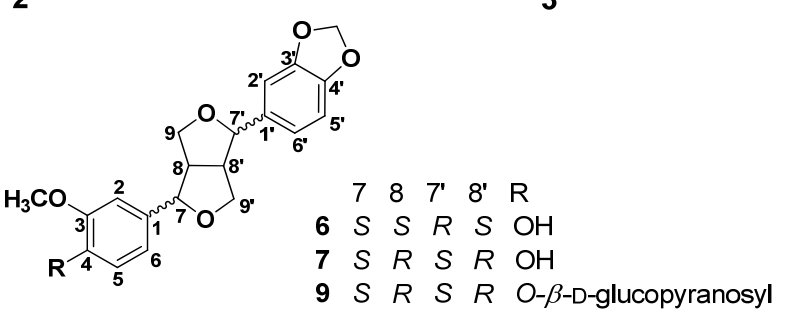

Compound 1, obtained as colorless crystals from methanol, exhibited a UV absorption maximum at $282 \mathrm{~nm}$. The molecular formula was determined to be $\mathrm{C}_{20} \mathrm{H}_{24} \mathrm{O}_{6}$ from the molecular ion peak [M] ${ }^{+}$at $m / z 360.1552$ (calcd for $\mathrm{C}_{20} \mathrm{H}_{24} \mathrm{O}_{6}, 360.1572$ ) in the HR-EIMS. IR absorption bands at 3,430, 1,648, and $1512 \mathrm{~cm}^{-1}$ were characteristic of hydroxyl and aromatic groups. The ${ }^{1} \mathrm{H}-\mathrm{NMR}$ spectrum showed three aromatic proton signals with $J_{4}$ coupling at $\delta_{\mathrm{H}} 6.90(1 \mathrm{H}, \mathrm{d}, J=3.2 \mathrm{~Hz}, \mathrm{H}-4), 6.76(1 \mathrm{H}$, overlapped, H-2), and 6.75 (1H, overlapped, H-6), which were assigned to a 1,3,5-trisubstituted benzene moiety. Three other aromatic proton signals at $\delta_{\mathrm{H}} 6.78\left(1 \mathrm{H}, \mathrm{d}, J=2.0 \mathrm{~Hz}, \mathrm{H}-2^{\prime}\right), 6.70(1 \mathrm{H}, \mathrm{d}$, $\left.J=8.0 \mathrm{~Hz}, \mathrm{H}-6^{\prime}\right)$, and $6.63\left(1 \mathrm{H}, \mathrm{dd}, J=8.0,2.0 \mathrm{~Hz}, \mathrm{H}-5^{\prime}\right)$ corresponded to another 1,2,4-trisubstituted 
benzene moiety. A doublet oxygenated methine proton signal at $\delta_{\mathrm{H}} 4.74(1 \mathrm{H}, J=6.8 \mathrm{~Hz})$, assigned to $\mathrm{H}-7$, and two oxygenated methyl proton signals at $\delta_{\mathrm{H}} 3.82(3 \mathrm{H})$ and $3.83(3 \mathrm{H})$ for two methoxy groups were observed. Two oxygenated methylene proton signals were observed at $\delta_{\mathrm{H}} 3.97(1 \mathrm{H}, \mathrm{dd}, J=8.4$, $6.8 \mathrm{~Hz}), 3.71(1 \mathrm{H}, \mathrm{dd}, J=8.4,6.8 \mathrm{~Hz}), 3.82(1 \mathrm{H}$, overlapped), and $3.62(1 \mathrm{H}, \mathrm{dd}, J=10.8,6.4 \mathrm{~Hz})$, which were assigned to $\mathrm{H}-9 \mathrm{a}, \mathrm{H}-9 \mathrm{~b}, \mathrm{H}-9$ 'a, and $\mathrm{H}-9$ 'b, respectively. In the high magnetic field, two methine proton signals at $\delta_{\mathrm{H}} 2.34(1 \mathrm{H}, \mathrm{m}, \mathrm{H}-8)$ and $2.72\left(1 \mathrm{H}, \mathrm{m}, \mathrm{H}-8^{\prime}\right)$, and two methylene proton signals at $\delta_{\mathrm{H}} 2.92\left(1 \mathrm{H}, \mathrm{dd}, J=13.2,4.8 \mathrm{~Hz}, \mathrm{H}-7\right.$ 'a) and $2.48\left(1 \mathrm{H}, \mathrm{dd}, J=13.2,11.6 \mathrm{~Hz}, \mathrm{H}-7{ }^{\prime} \mathrm{b}\right)$ were observed, suggesting the presence of a furan moiety. The ${ }^{13} \mathrm{C}-\mathrm{NMR}$ spectrum showed twenty carbon signals, including two methoxy carbon signals $\left[\delta_{\mathrm{C}} 56.3\right.$ (OMe-3,5)], confirming 1 to be a lignan. The multiplicity of each carbon was determined using a DEPT experiment. In the aromatic region, six olefin methine carbon signals [ $\delta_{\mathrm{C}} 122.1$ (C-6'), 119.8 (C-5'), 116.1 (C-2), 115.9 (C-6), 113.3 (C-2'), and $110.6(\mathrm{C}-4)$ ], two carbonated quaternary carbon signals $\left[\delta_{\mathrm{C}} 135.7(\mathrm{C}-1)\right.$ and $\left.133.5\left(\mathrm{C}-1^{\prime}\right)\right]$ and four oxygenated quaternary carbon signals $\left[\delta_{\mathrm{C}} 149.0(\mathrm{C}-3,5), 147.0\left(\mathrm{C}-4^{\prime}\right)\right.$, and $\left.145.7\left(\mathrm{C}-3^{\prime}\right)\right]$ due to the 1,3,5-tri- and 1,2,4-trisubstituted benzene moieties were observed. The oxygenated methine carbon signal at $\delta_{\mathrm{C}} 84.0(\mathrm{C}-7)$ shifted downfield due to attached to heteroatom $(-\mathrm{OH})$. Also, two oxygenated methylene carbon signals $\left[\delta_{\mathrm{C}} 73.4\left(\mathrm{C}-9^{\prime}\right)\right.$ and $\left.60.4(\mathrm{C}-9)\right]$ and two methoxy carbon signals $\left[\delta_{\mathrm{C}} 56.3\right.$ $(3,5-\mathrm{OMe})]$ were observed. In the high magnetic field, two methine carbon signals $\left[\delta_{\mathrm{C}} 54.0(\mathrm{C}-8)\right.$ and $\left.43.8\left(\mathrm{C}-8^{\prime}\right)\right]$ and a methylene carbon signal $\left[\delta_{\mathrm{C}} 33.6\left(\mathrm{C}-7^{\prime}\right)\right]$ were observed. With further analysis of the HSQC and DEPT 135 spectra of $\mathbf{1}$, the proton and carbon NMR signals could be assigned (Table 1). The correlations in the ${ }^{1} \mathrm{H}-{ }^{1} \mathrm{H}$ COSY spectrum indicated key connectives of $\mathrm{H}-8\left(\delta_{\mathrm{H}} 2.34\right)$ with $\mathrm{H}-7$ $\left(\delta_{\mathrm{H}} 4.74\right), \mathrm{H}-8^{\prime}\left(\delta_{\mathrm{H}} 2.72\right), \mathrm{H}-9 \mathrm{a}\left(\delta_{\mathrm{H}} 3.97\right)$, and H-9b $\left(\delta_{\mathrm{H}} 3.71\right)$ and $\mathrm{H}-8^{\prime}\left(\delta_{\mathrm{H}} 2.72\right)$ with $\mathrm{H}-7^{\prime} \mathrm{b}\left(\delta_{\mathrm{H}} 2.48\right)$, $\mathrm{H}-9$ 'a $\left(\delta_{\mathrm{H}} 3.82\right)$, and $\mathrm{H}-9$ 'b $\left(\delta_{\mathrm{H}} 3.62\right)$ (Figure 2$)$. In the HMBC spectrum, the long-range correlations of the two aromatic rings with the tetrahydrofuran ring were indicated by cross peaks between $\mathrm{H}-7\left(\delta_{\mathrm{H}}\right.$ 4.74) and C-2 $\left(\delta_{\mathrm{C}} 116.1\right), \mathrm{C}-6\left(\delta_{\mathrm{C}} 115.9\right)$, and C-9 $\left(\delta_{\mathrm{C}} 60.4\right)$ and between H-7' $\left(\delta_{\mathrm{H}} 2.92,2.48\right)$ and C-1' $\left(\delta_{\mathrm{C}} 133.5\right), \mathrm{C}-2^{\prime}\left(\delta_{\mathrm{C}} 113.3\right)$, and $\mathrm{C}-6^{\prime}\left(\delta_{\mathrm{C}} 122.1\right)$ (Figure 2$)$. In addition, the long-range correlations between the proton signals of methoxy $\left(\delta_{\mathrm{H}} 3.82,3.83\right)$ and the oxygenated quaternary carbon signals of C-3, $5\left(\delta_{\mathrm{c}} 149.0\right)$ were also identified. The relative stereochemistry of H-8 and H-8' 1 was identified as trans from the lack of NOE effect between $\mathrm{H}-8$ and H- $8^{\prime}$. The coupling constant of $6.8 \mathrm{~Hz}$ between H-7 and H-8, as well as the optical rotation of $\mathbf{1}\left([\alpha]^{25}{ }_{\mathrm{D}}=-43.5^{\circ}\right)$ suggested an $S$ configuration at C-7 [13]. A lignan with $7 S$ and $8 R$ configuration of similar structure, $(3 R, 4 R)-4-[(S)$-(hydroxy)(4-hydroxy-3methoxyphenyl)methyl]-3-(4-hydoxy-3-methoxybenzyl)tetrahydrofuran $\left([\alpha]^{20}{ }_{\mathrm{D}}=-49^{\circ}\right)$, supported the above, as reported in the literature [14]. The ${ }^{13} \mathrm{C}-\mathrm{NMR}$ spectra (C-7, C-8, C-7', C-8') and NOESY experiment of 1 was very similar to $(+)$ tripterygiol except for the optical rotation $\left([\alpha]^{25}{ }_{\mathrm{D}}=+48.3^{\circ}\right)$ and were comparable to the epi-THF lignan [15]. This indicates that the H-8 and H-8' are present in (7S,8R)-configuration.

Finally, the structure of 1 was determined to be 3-(3',4'-dihydroxybenzyl)-4-[(7S),7-hydroxy-3,5dimethoxybenzyl]tetrahydrofuran, and named acanthosessilin A. Comparisons of NMR and MS data for the known compounds 2-9 with reported values led to their identification as (-)-sesamin (2) [16], (-)-hinokinin (3) [3], (+)-syringaresinol (4) [16], (+)-pinoresinol (5) [17], (+)-piperitol (6) [18], (+)-xanthoxylol (7) [19], acanthoside B (8) [20], and simlexoside (9) [21], respectively (Figure 1). Compounds 1, 6, 7, and 9 were isolated from the genus Acanthopanax for the first time. In addition, compounds $\mathbf{3}$ and $\mathbf{5}$ were also isolated from this plant for the first time. 
Table 1. ${ }^{1} \mathrm{H}-(400 \mathrm{MHz})$ and ${ }^{13} \mathrm{C}-\mathrm{NMR}(100 \mathrm{MHz})$ data of compound $\mathbf{1}$ (in $\mathrm{CD}_{3} \mathrm{OD}, \delta$ in ppm, $J$ in $\mathrm{Hz})^{\text {a }}$.

\begin{tabular}{cccccc}
\hline No. & $\boldsymbol{\delta}_{\mathbf{H}}$ & $\boldsymbol{\delta}_{\mathbf{C}}$ & No. & $\boldsymbol{\delta}_{\mathbf{H}}$ & $\boldsymbol{\delta}_{\mathbf{C}}$ \\
\hline 1 & & 135.7 & $1^{\prime}$ & & 133.5 \\
2 & $6.76(1 \mathrm{H}$, overlapped $)$ & 116.1 & $2^{\prime}$ & $6.78(1 \mathrm{H}, \mathrm{d}, J=2.0 \mathrm{~Hz})$ & 113.3 \\
3 & & 149.0 & $3^{\prime}$ & & 145.7 \\
4 & $6.90(1 \mathrm{H}, \mathrm{d}, J=3.2 \mathrm{~Hz})$ & 110.6 & $4^{\prime}$ & & 147.0 \\
5 & & 149.0 & $5^{\prime}$ & $6.70(1 \mathrm{H}, \mathrm{d}, J=8.0 \mathrm{~Hz})$ & 119.8 \\
6 & $6.75(1 \mathrm{H}$, overlapped $)$ & 115.9 & $6^{\prime}$ & $6.63(1 \mathrm{H}, \mathrm{dd}, J=8.0,2.0 \mathrm{~Hz})$ & 122.1 \\
7 & $4.74(1 \mathrm{H}, \mathrm{d}, J=6.8)$ & 84.0 & $7^{\prime}$ & $2.92\left(1 \mathrm{H}, \mathrm{dd}, J=13.2,4.8 \mathrm{~Hz}, \mathrm{H}-7^{\prime} \mathrm{a}\right)$ & 33.6 \\
8 & $2.34(1 \mathrm{H}, m)$ & 54.0 & $8^{\prime}$ & $2.48\left(1 \mathrm{H}, \mathrm{dd}, J=13.2,11.6 \mathrm{~Hz}, \mathrm{H}-7^{\prime} \mathrm{b}\right)$ & \\
& $3.97(1 \mathrm{H}, \mathrm{dd}, J=8.4,6.8, \mathrm{H}-9 \mathrm{a})$ & 60.4 & $9^{\prime}$ & $3.82(1 \mathrm{H}, \mathrm{overlapped}, \mathrm{H}-9$ 'a $)$ & 73.8 \\
9 & $3.71(1 \mathrm{H}, \mathrm{dd}, J=8.4,6.8, \mathrm{H}-9 \mathrm{~b})$ & & & & \\
$3-\mathrm{OCH}_{3}$ & $3.83(3 \mathrm{H}, \mathrm{s})$ & 56.3 & & & \\
$5-\mathrm{OCH}_{3}$ & $3.82(3 \mathrm{H}, \mathrm{s})$ & 56.3 & & & \\
\hline
\end{tabular}

${ }^{\mathrm{a}}$ Assignments were confirmed by DEPT, ${ }^{1} \mathrm{H}-{ }^{1} \mathrm{H}$ COSY, HSQC, and HMBC.

Figure 2. Key ${ }^{1} \mathrm{H}-{ }^{1} \mathrm{H}$ COSY (bold dash) and HMBC (arrow) correlations of compound $\mathbf{1}$.

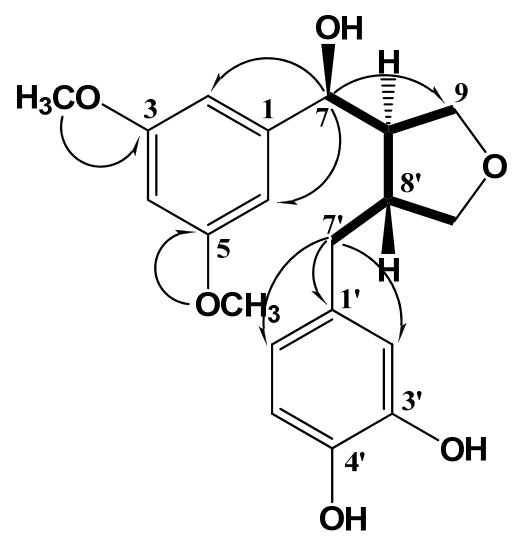

Previous studies have already reported on the anti-inflammatory effects of components from A. sessiliflorus $[11,12]$. Since NO is known to play an important role in the inflammatory process, inhibitors of NO production are considered as potential anti-inflammatory agents [22]. Thus, we also investigated the inhibitory effects of compounds (1-9) on NO production by using the Griess reaction to measure nitrite, a soluble oxidation product of NO, in the culture medium of LPS-induced RAW 264.7 macrophages. As shown in Table 2, compounds 3-7 moderately inhibited NO production with $\mathrm{IC}_{50}$ values of $21.56,17.75,10.34,22.30$, and $27.57 \mu \mathrm{M}$, respectively. Compounds $\mathbf{1}, \mathbf{2}, \mathbf{8}$, and 9 also decreased NO production with $\mathrm{IC}_{50}$ values in the range of 49.94 to $65.07 \mu \mathrm{M}$. Some cell toxicity was observed in cells treated with compounds $\mathbf{3}$ and $\mathbf{9}$, whereas other compounds had no influence on cell viability. 
Table 2. Inhibitory effects of compounds 1-9 against LPS-Induced NO production in RAW 264.7 macrophage cells.

\begin{tabular}{ccc}
\hline Compound & $\mathbf{I C}_{\mathbf{5 0}}(\boldsymbol{\mu M})^{\mathbf{a}}$ & Cell viability (\%) $^{\mathbf{b}}$ \\
\hline $\mathbf{1}$ & $49.94 \pm 6.56$ & $84.81 \pm 2.71$ \\
$\mathbf{2}$ & $38.92 \pm 2.86$ & $95.52 \pm 2.01$ \\
$\mathbf{3}$ & $21.56 \pm 1.19$ & $50.21 \pm 1.55$ \\
$\mathbf{4}$ & $17.75 \pm 1.15$ & $80.21 \pm 1.11$ \\
$\mathbf{5}$ & $10.34 \pm 2.37$ & $81.50 \pm 3.32$ \\
$\mathbf{6}$ & $22.30 \pm 1.10$ & $84.11 \pm 2.46$ \\
$\mathbf{7}$ & $21.57 \pm 1.28$ & $88.43 \pm 3.71$ \\
$\mathbf{8}$ & $65.07 \pm 8.02$ & $82.42 \pm 1.27$ \\
$\mathbf{9}$ & $53.00 \pm 2.75$ & $54.52 \pm 2.21$ \\
Aminoguanidine $^{\mathbf{c}}$ & $6.51 \pm 1.15$ & $84.61 \pm 2.50$ \\
\hline
\end{tabular}

${ }^{\mathrm{a}} \mathrm{IC}_{50}$ value of each compound was defined as the concentration $(\mu \mathrm{M})$ that caused $50 \%$ inhibition of NO production in LPS-activated RAW 264.7 macrophage cells. Cells were pretreated for $1 \mathrm{~h}$ with compounds before stimulation with LPS $(1 \mu \mathrm{g} / \mathrm{mL})$ for $24 \mathrm{~h}$; ${ }^{\text {b }}$ Cell viability indicates mean maximum inhibitory effect, at a concentration of $100 \mu \mathrm{M}$, expressed as a percentage inhibition of nitrite production induced by LPS $(1 \mu \mathrm{g} / \mathrm{mL})$ in the presence of vehicle; ${ }^{\mathrm{c}}$ Positive control. The results are averages of three independent experiments, and the data are expressed as mean $\pm \mathrm{SD}$.

\section{Experimental}

\subsection{General}

Melting points were obtained using a Fisher-Johns Melting Point Apparatus with a microscope. Ultraviolet spectra were measured on a Shimadzu model UV-1601 spectrophotometer. CD spectra were obtained with a JASCO 715 spectropolarimeter. Optical rotations were measured on a JASCO P-1010 digital polarimeter. ${ }^{1} \mathrm{H}-,{ }^{13} \mathrm{C}$-, and 2D-NMR spectra were recorded on a Varian Unity Inova AS 400 FT-NMR instrument, and chemical shifts were given in $\delta$ (ppm) based on tetramethylsilane (TMS) as an internal standard. IR spectra were run on a Perkin Elmer Spectrum One FT-IR spectrometer. EIMS and HR-EIMS spectra were obtained using a JEOL JMS-700 mass spectrometer (Tokyo, Japan). Silica gel 60 (Merck, 230-400 mesh), LiChroprep RP-18 (Merck, 40-63 $\mu \mathrm{m}$ ), and Sephadex LH-20 (Amersham Pharmacia Biotech., Uppsala, Sweden) were used for column chromatography (CC). Pre-coated silica gel plates (Merck, Kieselgel $60 \mathrm{~F}_{254}, 0.25 \mathrm{~mm}$ ) and pre-coated RP-18 $\mathrm{F}_{254 \mathrm{~s}}$ plates (Merck) were used for analytical thin-layer chromatography analyses. Spots were visualized by spraying with $10 \%$ aqueous $\mathrm{H}_{2} \mathrm{SO}_{4}$ solution followed by heating.

\subsection{Plant Material}

The fruits of $A$. sessiliflorus were provided by the Jeongseon Agricultural Extension Center, Jeongseon, Korea in August 2009 and were identified by Prof. Dae-Keun Kim, College of Pharmacy, Woo Suk University, Jeonju, Korea. A voucher specimen (KHU090809) was reserved at the Laboratory of Natural Products Chemistry, Kyung Hee University, Yongin, Korea. 


\subsection{Extraction and Isolation}

The air-dried fruits of $A$. sessiliflorus $(10 \mathrm{~kg})$ were powdered and extracted three times with $36 \mathrm{~L}$ of aqueous $70 \% \mathrm{EtOH}$ at room temperature for $24 \mathrm{~h}$. After concentration in vacuo, the EtOH extract $(2,012 \mathrm{~g})$ was suspended in $\mathrm{H}_{2} \mathrm{O}(3 \mathrm{~L})$ and then partitioned with EtOAc $(3 \mathrm{~L} \times 3)$ followed by concentration to give the EtOAc fraction (E, $118 \mathrm{~g})$. Fraction E (100 g) was subjected to a silica gel $\mathrm{CC}(15 \times 21 \mathrm{~cm})$ using a gradient of $\mathrm{CH}_{3} \mathrm{Cl}_{3}-\mathrm{MeOH}(15: 1 \rightarrow 10: 1 \rightarrow 5: 1 \rightarrow 3: 1 \rightarrow 1: 1,2.8 \mathrm{~L}$ each $)$ to yield 14 fractions (E1 to E14). Fraction E1 [4.3 g, elution volume/total volume (Ve/Vt) 0.01-0.07] was subjected to the silica gel CC [5 $\times 10 \mathrm{~cm}, n$-hexane-EtOAc $(6: 1,4.5 \mathrm{~L})]$ to give compound 2 [486 mg, $\mathrm{Ve} / \mathrm{Vt}$ 0.43-0.60, (silica $\left.\mathrm{F}_{254}\right) \mathrm{R}_{\mathrm{f}}$ 0.55, $n$-hexane-EtOAc (2:1)]. Subfraction E1-17 (500 mg, Ve/Vt $0.48-0.77)$ was separated by CC $\left[\mathrm{RP}-18(3.5 \times 4 \mathrm{~cm})\right.$, acetone- $\left.\mathrm{H}_{2} \mathrm{O}(2: 1,1.5 \mathrm{~L})\right]$ to give compound 3 [22.7 mg, Ve/Vt 0.40-0.45, TLC (RP-18 $\left.\mathrm{F}_{254 \mathrm{~s}}\right) \mathrm{R}_{\mathrm{f}}$ 0.55, acetone- $\left.\mathrm{H}_{2} \mathrm{O}(1: 1)\right]$. Fraction E3 [36.3 g, $\mathrm{Ve} / \mathrm{Vt} 0.15-0.33]$ was subjected to the silica gel $\mathrm{CC}\left[6 \times 16 \mathrm{~cm}, \mathrm{CHCl}_{3}-\operatorname{EtOAc}(7: 1,5.5 \mathrm{~L})\right]$ to give five subfractions (E3-1 to E3-5). CC [silica gel $(3.5 \times 16 \mathrm{~cm}), n$-hexane-EtOAc $(1: 1,3 \mathrm{~L})$ ] of subfraction E3-3 (1.80 g, Ve/Vt 0.34-0.53) gave 19 subfractions (E3-3-1 to E3-3-19). Subfraction E3-3-13 $\left(80 \mathrm{mg}, \mathrm{Ve} / \mathrm{Vt}\right.$ 0.36-0.51) was separated by CC [RP-18 $(3.5 \times 5.5 \mathrm{~cm})$, acetone-MeOH- $\mathrm{H}_{2} \mathrm{O}(1: 1: 3$, $1.5 \mathrm{~L})$ ] to give compound 1 [11 $\mathrm{mg}, \mathrm{Ve} / \mathrm{Vt}$ 0.22-0.33, TLC (RP-18 $\left.\mathrm{F}_{254 \mathrm{~s}}\right) \mathrm{R}_{\mathrm{f}}$ 0.55, acetone- $\left.\mathrm{MeOH}-\mathrm{H}_{2} \mathrm{O}(1: 2: 1)\right]$. Fraction E8 (8.98 g, Ve/Vt 0.59-0.67) was fractionated using silica gel $\mathrm{CC}\left[4 \times 12 \mathrm{~cm}, \mathrm{CHCl}_{3}-\mathrm{MeOH}-\mathrm{H}_{2} \mathrm{O}(16: 3: 1 \rightarrow 13: 3: 1\right.$, each $\left.3.7 \mathrm{~L})\right]$ and yielded nine subfractions (E8-1 to E8-9). Subfraction E8-4 (1.85 g, Ve/Vt 0.45-0.58) was purified using CC [RP-18 $(3.5 \times 6.5 \mathrm{~cm})$, $\mathrm{MeOH}-\mathrm{H}_{2} \mathrm{O}(3: 1,1.2 \mathrm{~L})$ ] to give compound 4 [55 mg, Ve/Vt 0.56-0.70, TLC (RP-18 $\left.\mathrm{F}_{254 \mathrm{~s}}\right) \mathrm{R}_{\mathrm{f}} 0.40$, $\left.\mathrm{MeOH}-\mathrm{H}_{2} \mathrm{O}(5: 1)\right]$. Subfraction E8-5 (1.22 g, Ve/Vt 0.59-0.68) was fractionated using a Sephadex LH $20 \mathrm{CC}\left[3 \times 50 \mathrm{~cm}, \mathrm{MeOH}-\mathrm{H}_{2} \mathrm{O}(4: 1,1.8 \mathrm{~L})\right]$ and yielded five subfractions (E8-5-1 to E8-5-5). Purification of subfraction E8-5-4 (222 mg, Ve/Vt 0.75-0.88) using CC [RP-18 $(3 \times 10 \mathrm{~cm})$, EtOH- $\mathrm{H}_{2} \mathrm{O}(1: 3,0.5 \mathrm{~L})$ ] yielded compound 8 [44 mg, Ve/Vt 0.33-0.50, TLC (RP-18 $\left.\mathrm{F}_{254 \mathrm{~s}}\right) \mathrm{R}_{\mathrm{f}} 0.70$, EtOH- $\mathrm{H}_{2} \mathrm{O}$ (1:1)]. Subfraction E8-5-5 (146 mg, Ve/Vt 0.89-1.00) was separated by CC [RP-18 $\left.(30 \times 10 \mathrm{~cm}), \mathrm{MeOH}-\mathrm{H}_{2} \mathrm{O}(3: 1,1 \mathrm{~L})\right]$ to give compound 9 [20 mg, Ve/Vt 0.49-0.60, TLC (RP-18 $\left.\left.\mathrm{F}_{254 \mathrm{~s}}\right) \mathrm{R}_{\mathrm{f}} 0.50, \mathrm{MeOH}-\mathrm{H}_{2} \mathrm{O}(5: 1)\right]$. Fraction $\mathrm{E} 9(5.80 \mathrm{~g}, \mathrm{Ve} / \mathrm{Vt}$ 0.68-0.72) was fractionated using silica gel CC $\left[5 \times 18 \mathrm{~cm}, \mathrm{CH}_{3} \mathrm{Cl}_{3}-\mathrm{EtOH}-\mathrm{H}_{2} \mathrm{O}(16: 3: 1 \rightarrow\right.$ 13:3:1 $\rightarrow$ 10:3:1, each $\left.3.2 \mathrm{~L})\right]$ and yielded four subfractions (E9-1 to E9-4). Subfraction E9-4 (2.45 g, Ve/Vt 0.75-1.00) was chromatographed over $\mathrm{RP}-18(5 \times 5.5 \mathrm{~cm})$ and eluted with $\mathrm{MeOH}-\mathrm{H}_{2} \mathrm{O}(1: 1 \rightarrow 3: 1$, each $1.8 \mathrm{~L})$ to give twenty subfractions (E9-4-1 to E-9-4-20). Subfraction E9-4-1 (282 mg, Ve/Vt 0.01-0.12) was purified over silica gel CC $(4 \times 12 \mathrm{~cm})$ and eluted with $\mathrm{CHCl}_{3}-\mathrm{MeOH}-\mathrm{H}_{2} \mathrm{O}(14: 3: 1,2 \mathrm{~L})$ to give compound $\mathbf{1 0}$ [40 mg, $\mathrm{Ve} / \mathrm{Vt}$ 0.22-0.32, TLC (silica $\mathrm{F}_{254}$ ) $\mathrm{R}_{\mathrm{f}}$ 0.65, $\mathrm{CHCl}_{3}-\mathrm{MeOH}-\mathrm{H}_{2} \mathrm{O}$ (14:3:1)]. Subfraction E9-4-6 (190 mg, $\mathrm{Ve} / \mathrm{Vt} 0.55-0.64)$ was separated by $\mathrm{CC}\left[\mathrm{RP}-18(30 \times 10 \mathrm{~cm})\right.$, acetone $\left.-\mathrm{H}_{2} \mathrm{O}(1: 1,1.5 \mathrm{~L})\right]$ to give compound 6 [20 mg, Ve/Vt 0.49-0.60, TLC (RP-18 $\left.\mathrm{F}_{254 \mathrm{~s}}\right) \mathrm{R}_{\mathrm{f}} 0.55$, acetone- $\left.\mathrm{H}_{2} \mathrm{O}(2: 1)\right]$ and compound 7 [11 mg, Ve/Vt 0.66-0.71, TLC (RP-18 $\left.\mathrm{F}_{254 \mathrm{~s}}\right) \mathrm{R}_{\mathrm{f}} 0.50$, acetone- $\left.\mathrm{H}_{2} \mathrm{O}(2: 1)\right]$.

\subsection{Spectroscopic Data}

Acanthosessilin A (1). Colorless crystals, m.p.: $123-125{ }^{\circ} \mathrm{C} ;[\alpha]^{25}{ }_{\mathrm{D}}-43.5^{\circ}(c=0.5, \mathrm{MeOH}) ; \mathrm{CD}$ $\left(c=2.50 \times 10^{-3} \mathrm{M}, \mathrm{MeOH}\right) \lambda_{\max } \mathrm{nm}(\Delta \varepsilon):-0.42(217),-0.49$ (236); UV $\lambda_{\max }(\mathrm{MeOH}) \mathrm{nm}: 280 ; \mathrm{IR}$ 
$\left(\mathrm{CaF}_{2}\right.$ window $) \mathrm{cm}^{-1}: 3430,1648,1512,1245$; EIMS m/z: $360[\mathrm{M}]^{+}$; HR-EIMS m/z: 360.1552 [M] ${ }^{+}$ (calcd for $\mathrm{C}_{20} \mathrm{H}_{24} \mathrm{O}_{6}, 360.1572$ ); ${ }^{1} \mathrm{H}$ - and ${ }^{13} \mathrm{C}-\mathrm{NMR}$ data, see Table 1 .

\subsection{Measurement of NO Production and Cell Viability}

Assays for NO production and cell viability were carried out as previously described [23]. Briefly, RAW 264.7 macrophages were harvested and seeded in 96-well plates $\left(1 \times 10^{4}\right.$ cells/well $)$ for measurement of NO production. The plates were pretreated with various concentrations of samples for $30 \mathrm{~min}$ and incubated with LPS $(1 \mu \mathrm{g} / \mathrm{mL})$ for $24 \mathrm{~h}$. The amount of NO was determined by the nitrite concentration in cultured RAW264.7 macrophage supernatants using the Griess reagent. The cell viability was evaluated by MTT reduction.

\section{Conclusions}

The new compound 3-(3',4'-dihydroxybenzyl)-4-[(7S),7-hydroxy-3,5-dimethoxybenzyl]tetrahydrofuran, named acanthosessilin A (1), was isolated from Acanthopanax sessiliflorus, together with eight known lignans. According to previous investigations on Acanthopanax species, we have evaluated the inhibitory activities of all compounds against LPS-induced NO production in RAW264.7 macrophages. All compounds moderately inhibited $\mathrm{NO}$ production with $\mathrm{IC}_{50}$ values in the range of 10.34 to $65.07 \mu \mathrm{M}$. The results provide a potential explanation for the use of this plant as a herbal medicine in the treatment of inflammatory diseases, and they may be potentially useful in developing new anti-inflammatory agents.

\section{Supplementary Materials}

${ }^{1} \mathrm{H}-\mathrm{NMR},{ }^{13} \mathrm{C}-\mathrm{NMR}$, EIMS, and HR-EIMS spectra of $\mathbf{1}$ are available as supporting data, which can be accessed at: http://www.mdpi.com/1420-3049/18/1/41/s1.

\section{Acknowledgements}

This work was supported by the 2012 Post-Doctoral Fellowship Program of NIHH and Cooperative Research Program for Agricultural Science \& Technology Development (Project No. PJ008700), Rural Development Administration, Korea.

\section{References}

1. Song, L.; Wu, Y.; Hu, L.; Zhang, G.; Xu, G.; Xiao, P.; Ling, Y.; Ding, X.; Cao, C.; Li, Y. Zhong Hua Ben Cao; Shanghai Scientific Technologic Publisher: Shanghai, China, 1999; Volume 5, p. 765.

2. Jung, B.S.; Shin, M.K. Hyang Yak Dae Sa Jeon, 3rd ed.; Young Lim Sa Publisher: Seoul, Korea, 2003; p. 432.

3. Cai, X.F.; Lee, I.S.; Dat, N.T.; Shen, G.; Kang, J.S.; Kim, D.H.; Kim, Y.H. Inhibitory lignans against NFAT transcription factor from Acanthopanax koreanum. Arch. Pharm. Res. 2004, 27, $738-741$. 
4. Hong, S.S.; Hwang, J.S.; Lee, S.A.; Hwang, B.Y.; Ha, K.W.; Ze, K.R.; Seung, R.S.; Ro, J.S.; Lee, K.S. Isolation and quantitative analysis of acanthoside D from Acanthopanacis cortex. Saengyak Hakhoechi 2001, 32, 316-321.

5. Yook, C.S.; Rho, Y.S.; Seo, S.H.; Leem, J.Y.; Han, D.R. Chemical components of Acanthopanax divaricatus and anticancer effect in leaves. Yakhak Hoechi 1996, 40, 251-261.

6. Kim, H.M.; Kim, J.S.; Lee, S.H.; Lee, S.J.; Lee, G.P.; Kang, S.S.; Cho, S.H.; Cheoi, D.S. Quantitative analysis of lignans in the fruits of Acanthopanax species by HPLC. Food Sci. Biotechnol. 2006, 15, 778-780.

7. Lee, S.H.; Son, D.W.; Ryu, J.Y.; Lee, Y.S.; Jung, S.H.; Kang, J.G.; Lee, S.Y.; Kim, H.S.; Shin, K.H. Anti-oxidant activities of Acanthopanax senticosus stems and their lignan components. Arch. Pharm. Res. 2004, 27, 106-110.

8. Lyu, S.Y.; Park, W.B. Modulation of IL-12 and IFN- $\gamma$ secretions by eleutheroside E, tortoside A, and syringaresinol from Acanthopanax koreanum Nakai. Biomol. Ther. 2010, 18, 211-218.

9. Li, S.C. Bencao Gangmu (Compendium of Materia Medica); Ko Mun Sa Publisher: Seoul, Korea, 1993; Volume 36, p. 26.

10. Hong, J.J.; Shin, K.H.; Lim, S.S.; Kwak, J.H.; Zee, O.P.; Ishihara, K.; Hirasawa, N.; Seyama, T.; Ohuchi, K. Lead compounds for anti-inflammatory drugs isolated from the plants of the traditional oriental medicine in Korea. Curr. Drug Targets Inflamm. Allergy 2008, 7, 195-202.

11. Jung, H.J.; Nam, J.H.; Choi, J.W.; Lee, K.T.; Park, H.J. Anti-inflammatory effects of chiisanoside and chiisanogenin obtained from the leaves of Acanthopanax chiisanensis in the carrageenan- and Freund's complete adjuvant-induced rats. J. Ethnopharmacol. 2005, 97, 359-367.

12. Jung, H.J.; Park, H.J.; Kim, R.G.; Shin, K.M.; Ha, J.H.; Choi, J.W.; Kim, H.J.; Lee, Y.S.; Lee, K.T. In vivo anti-inflammatory and antinociceptive effects of liriodendrin isolated from the stem bark of Acanthopanax senticosus. Planta Med. 2003, 69, 610-616.

13. Hanuman, J.B.; Mishra, A.K.; Sabata, B. A natural phenolic lignan from Tinospora cordifolia Miers. J. Chem. Soc. Perkin Trans. 1 1986, 7, 1181-1185.

14. Yamauchi, S.; Hayashi, Y.; Nakashima, Y.; Kirikihira, T.; Yamada, K.; Masuda, T. Effect of benzylic oxygen on the antioxidant activity of phenolic lignans. J. Nat. Prod. 2005, 68, 1459-1470.

15. Ma, J.; Dey, M.; Yang, H.; Poulev, A.; Pouleva, R.; Dorn, R.; Lipsky, P.E.; Kennelly, E.J.; Raskin, I. Anti-inflammatory and immunosuppressive compounds form Tripterygium wilfordii. Phytochemistry 2007, 68, 1172-1178.

16. Ryu, J.Y.; Son, D.W.; Kang, J.G.; Kim, H.S.; Kim, B.K.; Lee, S.H. A benzenoid from the stem of Acanthopanax senticosus. Arch. Pharm. Res. 2004, 27, 912-914.

17. Lee, D.Y.; Song, M.C.; Yoo, K.H.; Bang, M.H.; Chung, I.S.; Kim, S.H.; Kim, D.K.; Kwon, B.M.; Jeong, T.S.; Park, M.H. Lignans from the fruits of Cornus kousa Burg and their cytotoxic effects on human cancer cell lines. Arch. Pharm. Res. 2007, 30, 402-407.

18. Takaku, N.; Choi, D.H.; Mikame, K.; Okunishi, T.; Suzuki, S.; Ohashi, H.; Umezawa, T.; Shimada, M. Lignans of Chamaecyparis obtuse. J. Wood Sci. 2001, 47, 476-482.

19. Fang, J.M.; Lee, C.K.; Cheng, Y.S. Lignans from leaves of Juniperus chinensis. Phytochemistry 1992, 31, 3659-3661. 
20. Nishibe, S.; Kinoshita, H.; Takeda, H.; Okano, G. Phenolic compounds from stem bark of Acanthopanax senticosus and their pharmacological effect in chronic swimming stressed rats. Chem. Pharm. Bull. 1990, 38, 1763-1765.

21. Ghosal, S.; Banerjee, S.; Jaiswal, D.K. Chemical constituents of Justica. Part 2. New furofurano lignans from Justicia simplex. Phytochemistry 1980, 19, 332-334.

22. Calixto, J.B.; Campos, M.M.; Otuki, M.F.; Santos, A.R.S. Anti-inflammatory compounds of plant origin. Part II. Modulation of pro-inflammatory cytokines, chemokines and adhesion molecules. Planta Med. 2004, 70, 93-103.

23. Jung, L.H.; Lee, D.Y.; Cho, J.G.; Lee, S.M.; Kang, H.C.; Seo, W.D.; Kang, H.W.; Kim, J.Y.; Baek, N.I. A new flavonolignan from the aerial parts of Oryza sativa L. inhibits nitric oxide production in RAW 264.7 macrophage cells. J. Korean Soc. Appl. Chem. 2011, 54, 865-870.

Sample Availability: Samples of the compounds 1-9 are available from the authors.

(C) 2013 by the authors; licensee MDPI, Basel, Switzerland. This article is an open access article distributed under the terms and conditions of the Creative Commons Attribution license (http://creativecommons.org/licenses/by/3.0/). 